\title{
The "New" University of Iowa: A Beaux-Arts Design for the Pentacrest
}

\author{
Nancy J. BrcaK and Jean W. Sizemore
}

IN 1898 the University of Iowa began an ambitious project to redesign a portion of its campus, an area that has come to be known as the Pentacrest. In that year, the university's Board of Regents asked the nationally known architect, Henry Van Brunt, to assist them in their program to expand and modernize the campus. With Van Brunt's help, the University of Iowa succeeded in formulating a grand architectural scheme to express its ideals, convey its public image, and address its need for expansion. Although the ensuing project was in part the result of particular circumstances at Iowa, it was also related to larger, national trends of its day.

The Pentacrest, the central campus of the University of Iowa, has always served several functions. Because it directly adjoins the main street of Iowa City, it presents the university's principal public facade to the town. Its buildings house many university classrooms and offices. It also provides a major open space in the center of campus and town. In many respects it is perceived as both the physical and symbolic heart of the campus.

The Pentacrest includes five buildings: Old Capitol, in the center, and four neoclassical structures marking its corners (fig. 1). The central building in this arrangement, a handsome Greek Revival edifice designed by John F. Rague, was begun in 1840 as the third territorial capitol of Iowa and became the first capitol of the State of Iowa in 1846 (fig. 2). The four newer build-

THE ANNALS OF IOWA 51 (Fall 1991). CThe State Historical Society of Iowa, 1991. 


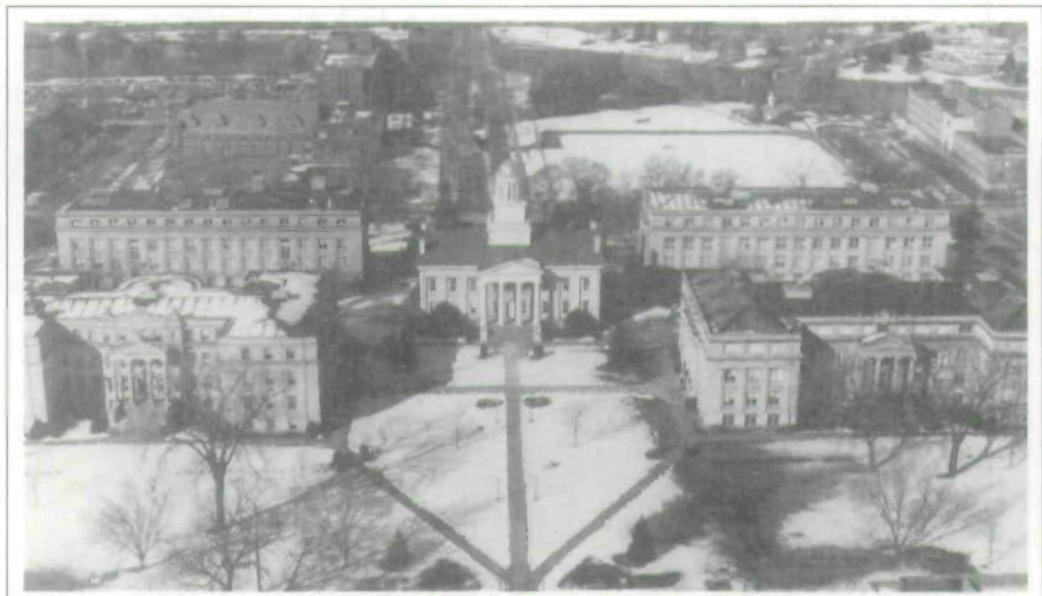

Fig. 1. The Pentacrest, 1898-1924. View to the west showing Old Capitol at center and, clockwise from lower left: Schaeffer, MacLean, Jessup, and Macbride halls. Courtesy of University of Iowa Libraries, Iowa City.

ings, all designed by the Des Moines architectural firm of Proudfoot and Bird, were constructed by the university over the years extending from 1898 to $1924 .^{1}$

Implementation of the Pentacrest design involved considerably more than erecting the four neoclassical buildings; it required the destruction of existing fabric and the rethinking of all elements of the central campus. The existing campus, with

1. When the state government was moved to Des Moines in 1857 , Old Capitol, as it came to be known, was deeded to the university, and it has served as a principal university building through the years. The other four buildings on the Pentacrest are Schaeffer Hall (1898-1902), Macbride Hall (1904-1908), MacLean Hall (1908-1912), and Jessup Hall (1924). George W. Bird and W. T. Proudfoot formed one of Iowa's major architectural firms for twenty years. They designed major buildings at all three state universities. Besides the four on the Pentacrest, two of their most monumental buildings are Beardshear Hall at Iowa State University (1902-1903) and the Polk County Courthouse at Des Moines (1902). Both architects were affiliated with the Americanized version of the Beaux-Arts, Proudfoot having studied briefly at the Massachusetts Institute of Technology and Bird in a Beaux-Arts atelier (The Tee Square $\mathrm{Club}$ ) in his native Philadelphia. Schaeffer Hall was their first major commission in Iowa and the first to be in the Beaux-Arts mode. After 1898 all of their major buildings were in that tradition. The most recent, thorough study of the firm is Patricia Eckhardt, "The Development of the University of Iowa Campus, 1898-1910" (Ph.D. diss., University of Iowa, 1990). We thank Dr. Eckhardt for sharing her research with us. 
its buildings and grounds set in a park-like atmosphere, reflected the mid-nineteenth-century picturesque attitude. It was no small undertaking for the university to impose an entirely new artistic point of view - a formal and monumental one in the new mode of Beaux-Arts Classicism-onto the earlier setting. Yet once the plan was set in the imagination of university officials, neither controversy, difficulty, nor expense could deter the Iowans in their quest for the new image.

The new arrangement features monumental neoclassical buildings of light-colored stone with uniform cornice heights arranged symmetrically around an imposing central building. This plan conveys the tremendous influence of the World's Columbian Exposition held in Chicago in 1893. The Exposition was a showcase for Beaux-Arts Classicism, which became a popular mode for American city and campus planning after the Exposition, for it seemed to crystallize some current national concerns and civic ideals. At the same time, it coincided with the needs and goals of officials at the University of Iowa.

THE BEAUX-ARTS MODE OF DESIGN (or "Beaux-Arts Classicism" as some style books term it) derived its name from the famous Parisian school of architecture where it was origi-

Fig. 2. Old Capitol, 1840. Courtesy of University of Iowa Libraries.

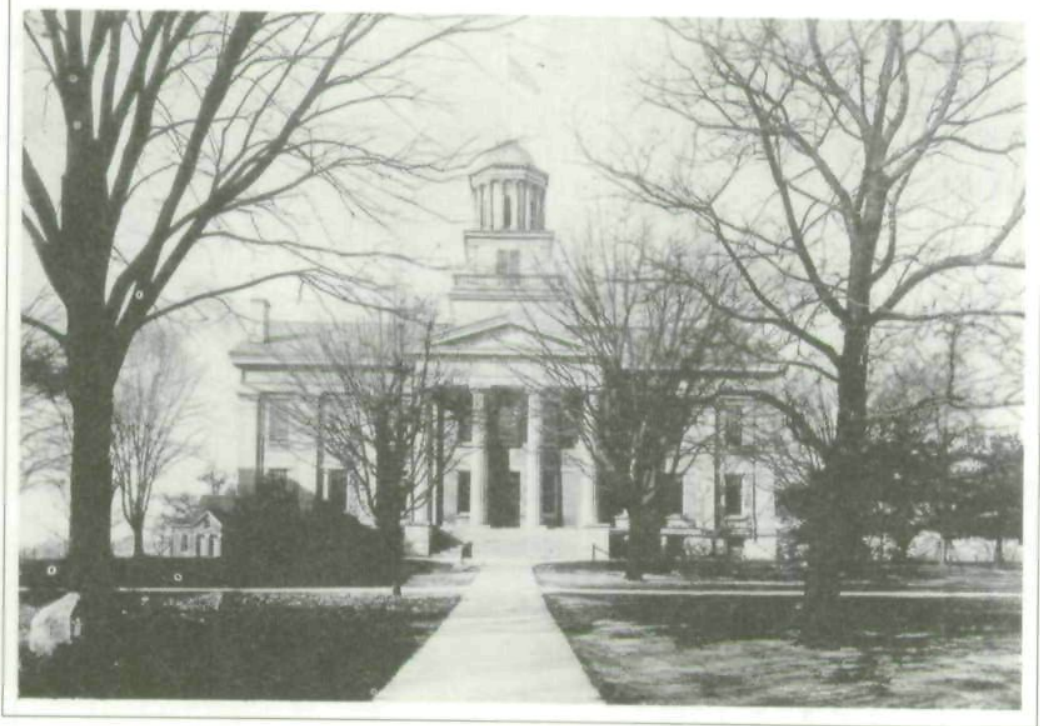


nally formulated, the École des Beaux-Arts. Beaux-Arts Classicism placed emphasis on symmetry, classical details, monumental forms, and, above all, the careful organization and clear relationship of the overall design to its parts. Thus, architectural design was seen as a rational, coherent process, a series of problems to be identified and solved through the application of formal rules. After the exuberant, free-wheeling, picturesque eclecticism of High Victorian architecture, the new mode was welcomed by the American architectural establishment as a return to reason, discipline, and order. Most young American architects aspired to study at the École des Beaux-Arts, and many did, especially between 1885 and World War I. But even if an aspiring young architectural student could not actually go to Paris, he or she could at least be taught by graduates of the school who were sought after as faculty members by all of the newly founded American schools of architecture. ${ }^{2}$

Ordinary Americans also found the new mode appealing because Beaux-Arts architects designed grandiose buildings based on classical principles that had, since ancient times, expressed the grandeur and dignity of civilization. In a period of intense and self-conscious nationalism, Americans approved of the grand yet dignified image of civic pride that this mode of architecture presented, an image linking the young culture to the great cultures of the past. ${ }^{3}$

The Columbian Exposition at Chicago in 1893 was the most important and influential showcase of Beaux-Arts Classicism the nation had seen. Hundreds of thousands of visitors were dazzled by the splendor of the "White City," especially by the Court of Honor, an elegant and harmonious ensemble of monumental neoclassical buildings with uniform cornice heights of sixty-five feet, their plaster facades painted white, all arranged symmetrically around a lagoon and an imposing cen-

2. For discussions of Beaux-Arts Classicism, see The Brooklyn Museum, The American Renaissance, 1876-1917 (Brooklyn, NY, 1979); Arthur Drexler, ed., The Architecture of the Ecole des Beaux-Arts (New York, 1977); and William Jordy, American Buildings and Their Architects: Progressive and Academic Ideals at the Turn of the Twentieth Century, vol. 3 (Garden City, NY, 1976).

3. Brooklyn Museum, The American Renaissance, 29-30. 


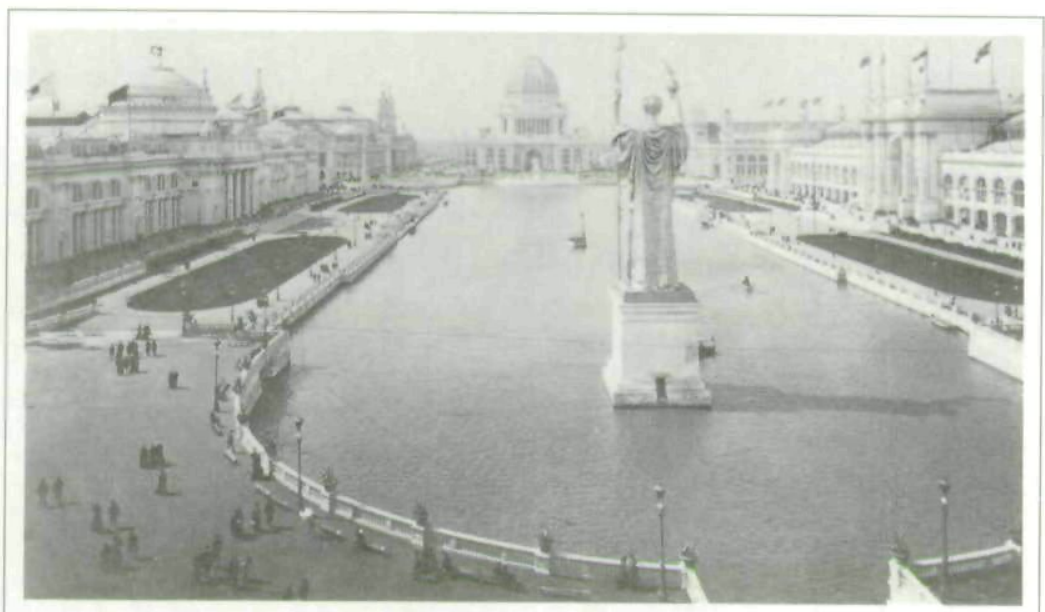

Fig. 3. Columbian Exposition, Chicago, 1893. Courtesy of Library of Congress, Washington, D.C.

tral domed building, and all lit by a new technological marvel, electric lights, creating glittering reflections in the lagoon (fig. 3). For most Americans, it was a novel visual experience to see the dignity and beauty of a unified and complete "city" plan, with squares, boulevards, lagoons, and plazas all electrically illuminated and landscaped. The Exposition helped change the architectural taste of the nation, and it also provided the impetus for modern city planning through the City Beautiful Movement. ${ }^{4}$

At a planning session for the Columbian Exposition, the sculptor Augustus St. Gaudens (himself a principal planner) remarked, "Gentlemen, do you realize that not since the Renaissance has a comparable group been brought together for an enterprise like this?"5 Never before had so many of America's

4. Daniel Burnham, chief planner for the 1893 Columbian Exposition, was the driving force behind the City Beautiful movement, which strove to bring order and beauty to the often chaotic urban landscape of late nineteenthcentury America. His most famous urban plan was the one for the city of Chicago that bore his name, but he was also responsible for turn-of-the-century city plans for San Francisco, Cleveland, and Washington, D.C.

5. Quoted in John William Reps, The Making of Urban America: A History of City Planning in the United States (Princeton, NJ, 1965), 500. 
most brilliant architects, artists, sculptors, and landscape architects gathered in one place. The grand spectacle reenforced the already current notion of the presence of an "American Renaissance." That notion carried several implications: that the maturation and burgeoning of all the arts in America made American culture at the turn of the century comparable to that of the Italian Renaissance; that, in the larger sense, art is closely identified with national greatness; and, of course, that art in the classical mode is superior. As historian Howard Wayne Morgan described the period, "In the broadest sense, art became identified with an image of civilization that was especially attractive to a rich, expansive, but uncertain generation. Emphasis on art and culture in general seemed part of a higher stage of development in every nation's history. The United States' turn had come and failure to embrace culture might arrest her general progress." 6

Thousands of visitors arrived daily at the Columbian Exposition on the railroads that by then criss-crossed the entire country. Once there, they witnessed the exposition's many scientific and industrial exhibits which dramatized America's emergence as the world leader in industrialization. For many Americans, progress also meant mobility, as all across the country people broke their ties with farms and small towns and moved to urban centers. Along with industrialization and urbanization, of course, came a new and unsettling awareness of ethnic and class differences. These changes brought dislocation or bewilderment to many people. To them, the visual unity and harmony presented at Chicago must have appeared especially attractive. $^{7}$

THE UNIVERSITY OF IOWA'S TRANSITION from a "simple college" to a modern university, which led to the whole Pentacrest scheme, acted out a part of the period's fundamental shift in values. George E. MacLean, who became president of the university in the midst of the transition, articulated the

6. Howard Wayne Morgan, New Muses: Art in American Culture, 1865-1920 (Norman, OK, 1978), 47.

7. See Robert Wiebe, The Search for Order, 1877-1920 (New York, 1967). 
main issues the university faced in a letter he wrote to David R. Boyd, president of Oklahoma University, in 1906. MacLean suggested that the university needed to expand its facilities in order to meet current needs, and to do so in a way that would allow for future expansion.

The campus of this university was inherited from the capitol square given to the University with the Old Capitol building in $1857 . .$. We began, therefore, with a totally inadequate campus. ... In those days it was supposed that a building the size of the ordinary capitol building would accommodate a university. With the wonderful progress of science and its application to the evolution of a genuine university as over against a college, we have reached a point where these state universities must have many buildings. ${ }^{8}$

Many other American colleges were undergoing similar transformations in the late nineteenth century. ${ }^{9}$ Their ambitions were related, in part, to a widespread spirit of reform, a desire for progress, a devotion to science, and a tremendous faith in education. They also resulted from the demands an increasingly industrialized society made on institutions of higher learning to produce the specialists an industrial society

8. MacLean to Boyd, 19 December 1906, MacLean File, University of Iowa Archives, Iowa City. MacLean was president from 1899 to 1911.

9. The situation was somewhat different at Iowa State University, and it is interesting to compare the look of the two campuses. Iowa State was established as a result of the Land Grant College Act of 1862, which was intended to create colleges for agricultural and mechanical education. Such colleges would presumably be more "democratic" than the older universities. Though founded in 1858, Iowa State did not open until 1869. When the older, more well-established University of Iowa at Iowa City attempted to secure a share of the funds at the state's disposal designated for the land-grant institution, Iowa State launched a successful campaign to garner all of the funds by contrasting the "urban-centered, sophisticated university and a simple rural farmers' college." Iowa State's campus was designed by the great landscape architect Frederick Law Olmsted, who had a special interest in the "people's colleges" and designed twenty of them. The Ames campus reflects the more informal and picturesque leanings of Olmsted's earlier designs, with its rural and park-like atmosphere with "modest buildings placed informally along meandering roads around a central park," as Paul Venable Turner described it in Campus: An American Planning Tradition (Cambridge, MA, 1984), 146. 


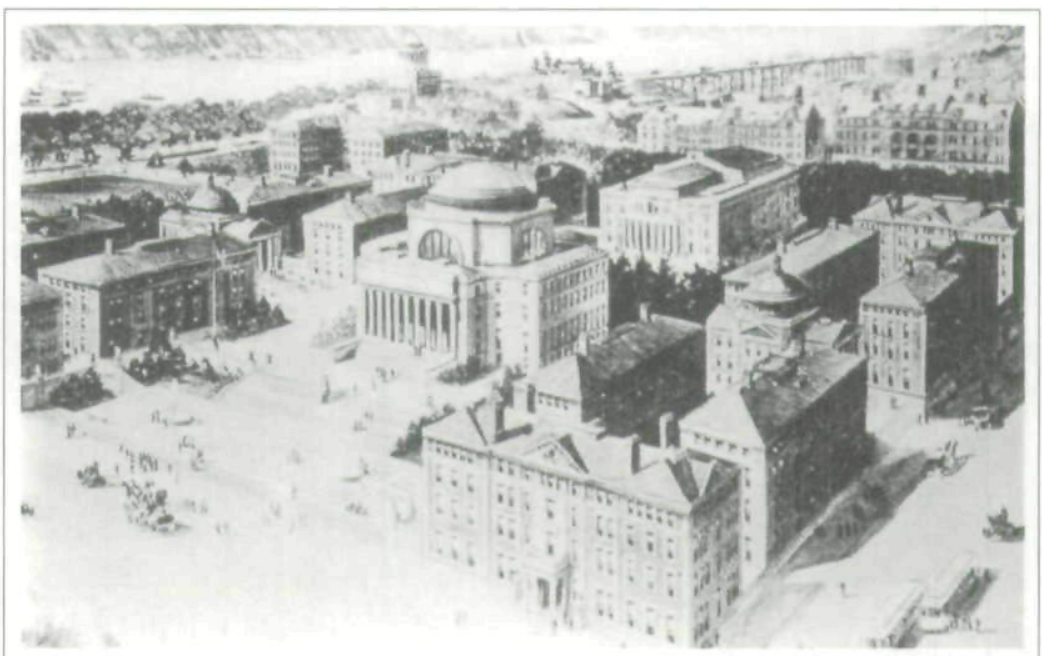

Fig. 4. Columbia University, 1894. Reprinted from Moses King, King's New York Views (New York, 1905).

needed. These new universities would have larger numbers of students with a corresponding need for more and different kinds of academic departments, housing facilities, libraries, and even museums.

President MacLean, like many other campus planners in the nation at the time, was concerned both with creating order and with giving visible expression to the excellence of the "new university." The University of Iowa's scheme could draw on many models of city and campus planning. At the new Columbia University in 1894, for example, Charles McKim had created a Beaux-Arts design much like the later Iowa scheme-a symmetrical grouping of neoclassical buildings around a central domed structure (fig. 4). ${ }^{10}$ Besides the general arrangement of the buildings, the Iowa project shared additional features and attitudes with the Columbia University design. Each, for example, made a conscious effort to relate the university com-

10. See Francesco Passanti, "The Design of Columbia University in the 1890s," Journal of the Society of Architectural Historians 36 (May 1977), 69-84. Passanti's essay deals with the original scheme of 1894 , not the 1903 modifications of that design. Comparisons here are, of course, with McKim's original proposal. 
plex to its urban setting, so the buildings faced outward toward the city rather than inward to form a quadrangle, the more popular arrangement on earlier campuses.

There was an important difference, however, between McKim's plan for Columbia and the University of Iowa scheme. Whereas at Columbia McKim had created a whole new campus, at Iowa the Beaux-Arts Pentacrest had to be imposed on an existing campus with an established visual tradition. At Iowa a crucial aspect of the design problem was the necessity of reconciling old and new traditions. President MacLean advised Oklahoma's President Boyd,

We are now working to plans made by Olmsted Brothers of Boston, not only with reference to the campus, but with reference to the location of buildings to come. The overwhelming majority of American universities have hodge podge buildings which are dropped here and there ... like ostrich eggs in the sand. I trust that your good people will forefend against these evils. At great cost we are redeeming this university from these defects. ${ }^{11}$

In his comments, MacLean was clearly espousing BeauxArts ideals, even if he did not name them. In addition, he praised the University of Washington at Seattle-remodeled in the Beaux-Arts manner in 1904 by the Olmsted brothers-as an example of a well-planned campus, able to meet the needs of a large, modern university in a dignified manner. He might also have cited the earlier axial site plan of imposing formality that Frederick Law Olmsted had created for Leland Stanford's

11. MacLean to Boyd, 19 December 1906. The great expense to which President MacLean referred was partly that incurred in moving Calvin Hall in 1905. Of the odd collection of Victorian-era buildings on the Old Capitol campus, Calvin Hall was one of the newest (having been built in 1884) and by far the most attractive and substantial. Through a remarkable engineering feat, the large brick building was moved across Jefferson Street with no interruption of classroom activities. Its removal from the Old Capitol area was a difficult project, and it represented a major step toward implementing the symmetrical five-part plan for the Pentacrest. Calvin Hall is still in use today in its present location on the northwest corner of Jefferson and Capitol Streets. For a summary of the process of moving Calvin Hall, see the Daily Iowan, 5 January 1906. 


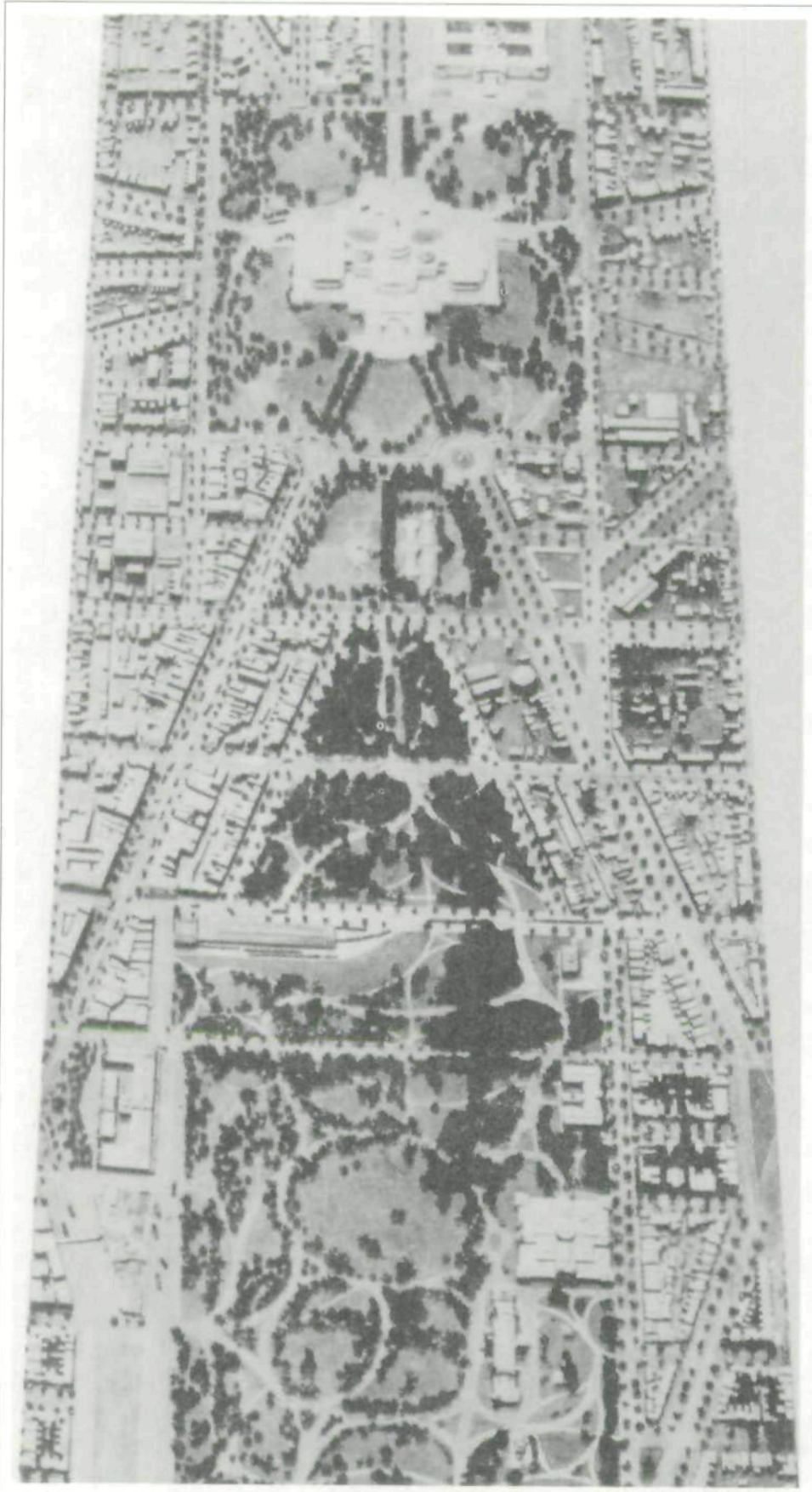

Fig. 5. Three-dimensional model of the Mall of the City of Washington, D.C., as it existed in 1901. Courtesy of Commission of Fine Arts, Washington, D.C. 


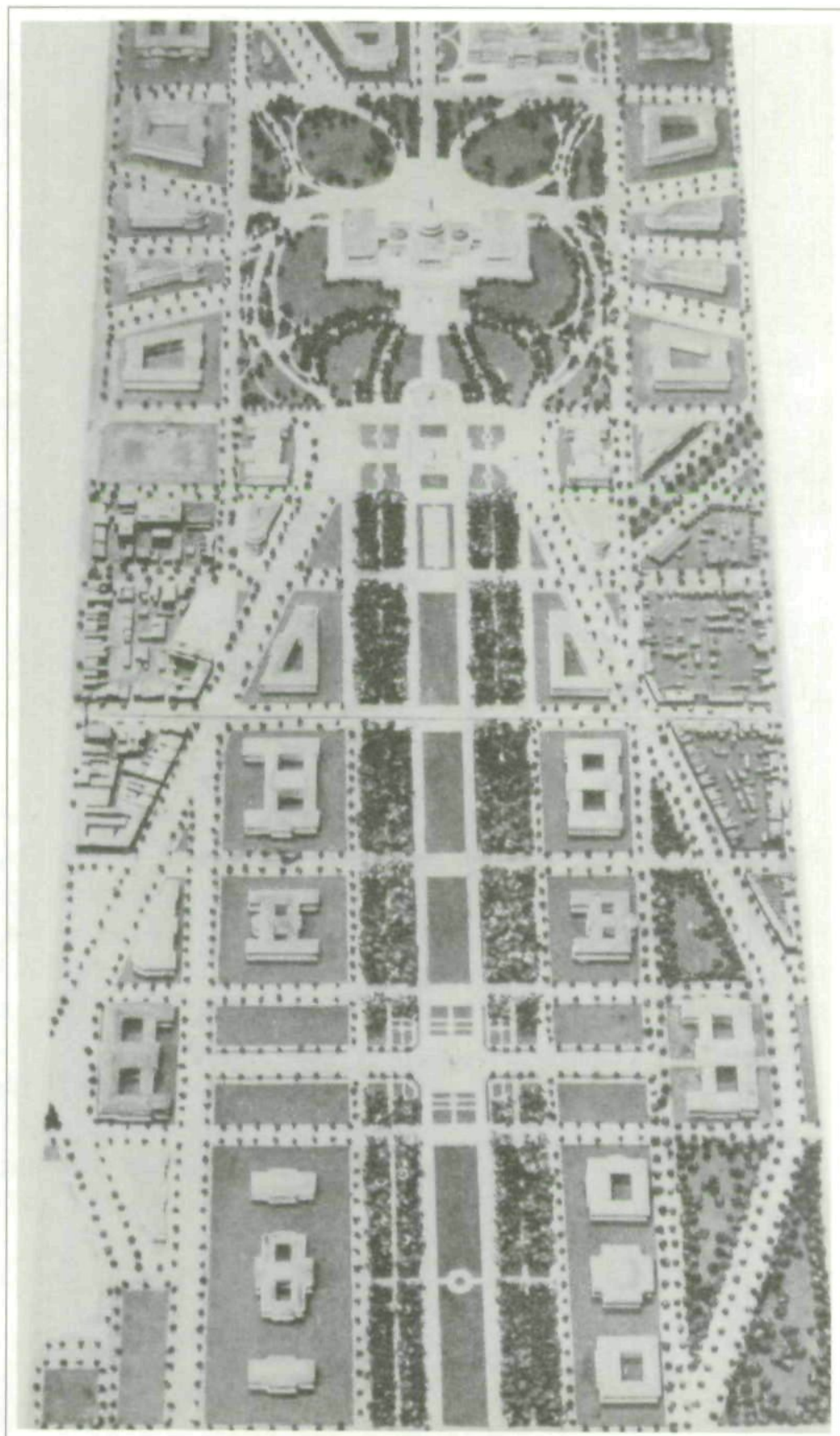

Fig. 6. Three-dimensional model of the design proposed by the McMillan Commission for the Mall of the City of Washington, D.C., 1901-1902. Courtesy of Commission of Fine Arts. 
newly founded university in Palo Alto, California, abandoning an earlier vision of a pastoral and picturesque campus. ${ }^{12}$

The aesthetic transformation at Iowa-and the controversy it caused-had civic antecedents as well as those associated with college campuses. The circumstances at Iowa resemble those surrounding the McMillan Commission's Beaux-Arts plan for the Mall in Washington, D.C. The commission, chaired by Daniel Burnham, recommended the sweeping transformation of an area familiar to and enjoyed by millions of Americans (fig. 5). The changes included the installation of a formal, axial arrangement of walkways, monumental neoclassical buildings, and plantings, all focusing on the U.S. Capitol (fig. 6). Considering inappropriate Andrew Jackson Downing's earlier landscape design in the mid-century picturesque tradition, the commission had it torn out. So great was the commission's zeal to replace the picturesque scheme with the newer Beaux-Arts one, it even suggested the destruction of one of the treasures of the Mall, James Renwick's romantic, castle-like Smithsonian Building. ${ }^{13}$

Old photographs and engravings suggest that a nineteenth-century picturesque tradition existed, on a more modest scale, at the University of Iowa before 1898 (figs. 7, 8, and cover). The red brick Victorian-era buildings, with their irregular lines and dark tonalities, set in a park-like wooded area, reflected picturesque attitudes. ${ }^{14}$ None of those early buildings was allowed to come forward of Old Capitol; indeed, all of them (except Calvin Hall) were in a straight line north and south of Old Capitol (fig. 7). Of varying functions and forms, those structures had been added piecemeal to the campus; and their construction in brick rather than stone suggests a concern for economy and utility, rather than for an imposing image.

12. MacLean to Boyd, 19 December 1906; Paul V. Turner, The Founders and the Architects: The Design of Stanford University (Stanford, CA, 1976), 25-26. We thank Professor Jean France of the University of Rochester for bringing the Turner catalog to our attention.

13. Smithsonian Institution, The Federal City: Plans and Realities (Washington, DC, 1976), xi, 90.

14. The Victorian structures included North Hall (1864-1865), "Old Dental" (1894), and Calvin Hall (1884) to the north of Old Capitol, and South Hall (1858-1860) and the Medical Building (1882) to the south. 


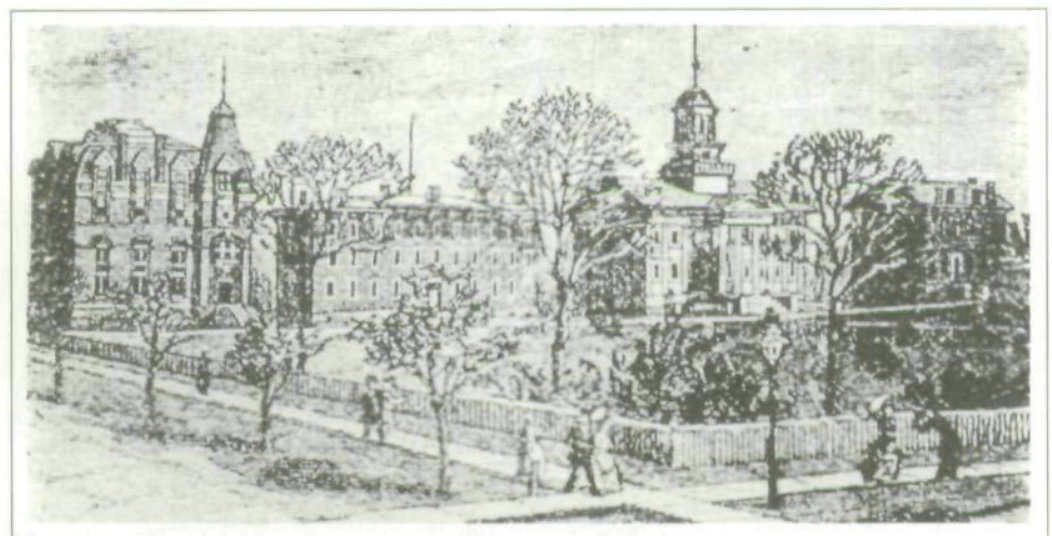

Fig. 7. Print of Old Capitol area, c. 1890. Courtesy of University of Iowa Libraries.

Also present in the earlier Victorian campus were cinder walks lined with locust trees, a rustic stone fountain, and a greatly prized one-hundred-year-old oak tree (fig. 8). The emphasis on large green spaces reflected Iowa's cherished rural values. ${ }^{15}$ These open areas were not simply backdrops for architecture; they were prized in and of themselves as settings for walks and traditional May breakfasts. So by the $1890 \mathrm{~s}$, when the new monumental scheme was being considered, a distinct visual tradition was already in place on the Iowa campus. The Beaux-Arts scheme's challenge to that visual tradition, with its encroachment on the campus's green space, soon sparked public opposition.

IN 1896 University of Iowa President Charles Schaeffer was finally successful in his long campaign to persuade the Iowa legislature to appropriate sufficient money for the university to begin considering a long-range building program for the central campus area. The project was inaugurated with a design competition for the first new building, Schaeffer Hall (fig. 1, bottom left, and fig. 9). A number of academic institutions used architectural competitions to aid them in establishing or expanding

15. About the rural quality of the fledgling university, the archives leave no doubt. In 1862, for example, the faculty voted to appropriate five dollars to allow the janitor, who lived in the basement of Old Capitol, to purchase a dog to assist him in keeping livestock off the campus. 


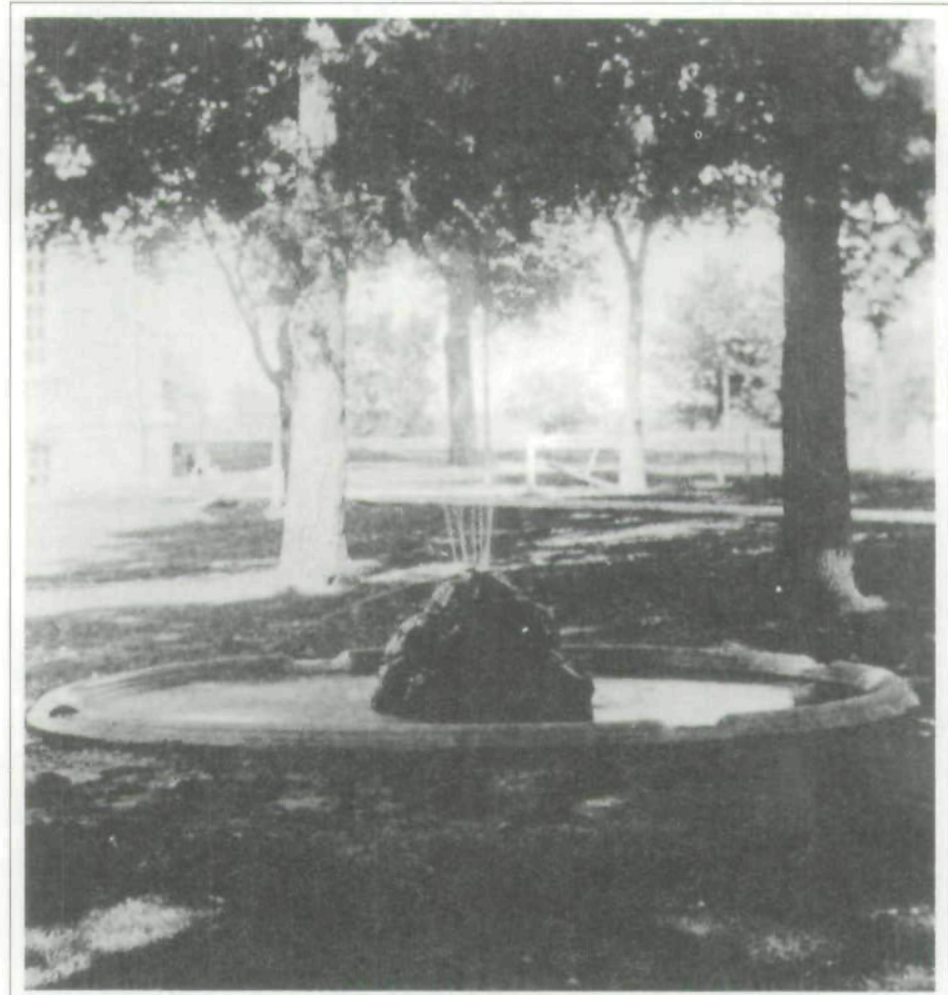

Fig. 8. Fountain, Old Capitol area, c. 1890. Courtesy of University of Iowa Libraries.

their facilities, and as Paul Turner has shown in his study of campus design, that approach was also a common European Beaux-Arts practice. ${ }^{16}$

By the close of Iowa's contest in 1898, the Board of Regents had received twenty-three design entries, representing a bewildering array of end-of-the-century eclectic styles. Unable to choose among these varied designs, the board made two important decisions: it voted to hold a second competition, this time asking eight of the architects to resubmit plans that would harmonize with Old Capitol; and it decided to ask Henry Van Brunt to assist in the selection of a design. ${ }^{17}$ When they chose

\section{Turner, Campus, 177.}

17. Circular, January 1898, Schaeffer Hall file, University of Iowa Archives, Iowa City. 
Van Brunt, the Regents must have had the 1893 Columbian Exposition on their minds. Van Brunt had formerly been associated with the nationally recognized firm of Ware and Van Brunt in Boston, but he was perhaps best known as the designer of the Electricity Building on the Court of Honor at the Exposition. Conveniently for the Iowans, by 1898 Van Brunt and his new partner, Frank Howe, had moved their offices to Kansas City.

The secretary of the Board of Regents explained the situation to Van Brunt.

The 23 samples of architecture examined by the Board were very miscellaneous. Some with high peaked roofs and steeples and they were called French Renaissance-others had no visible roof at all and that was pure Greek Renaissance. Others were called after other nations, but all were renascent. I think in fixing on the central building as a model, what the Board wanted was a good square turn of Iowa Renaissance for a change. ${ }^{18}$

Concerning Van Brunt's pivotal meeting with the Board of Regents, the official minutes record only that the board selected a design for Schaeffer Hall by the Iowa architects Proudfoot and Bird. ${ }^{19}$

A newspaper article announcing the winner of the competition suggested that the board was already thinking ahead to subsequent buildings and their arrangement on the campus. "The thought of the future is uppermost in the regents' mind as they plan. The central ideas are these: preservation of harmony, symmetry, and the park-like aspect of the campus ... [and] obscuration of unsightly old buildings.... Not only will the new building obscure the unsightly old medical building, but subsequent building of the new library will permit another eclipse, of the ugly old library building." 20

The board's decision to place Schaeffer Hall forward of Old Capitol-with the hint that other buildings would follow this arrangement-triggered a public outcry. Students and

18. W. J. Haddock to Henry Van Brunt, 11 March 1898, Schaeffer Hall file, University of Iowa Archives.

19. Minutes of the Board of Regents of the University of Iowa, 28 March 1898, Record Book C, 200, University of Iowa Archives.

20. Iowa State Press (Iowa City), 6 April 1898. 


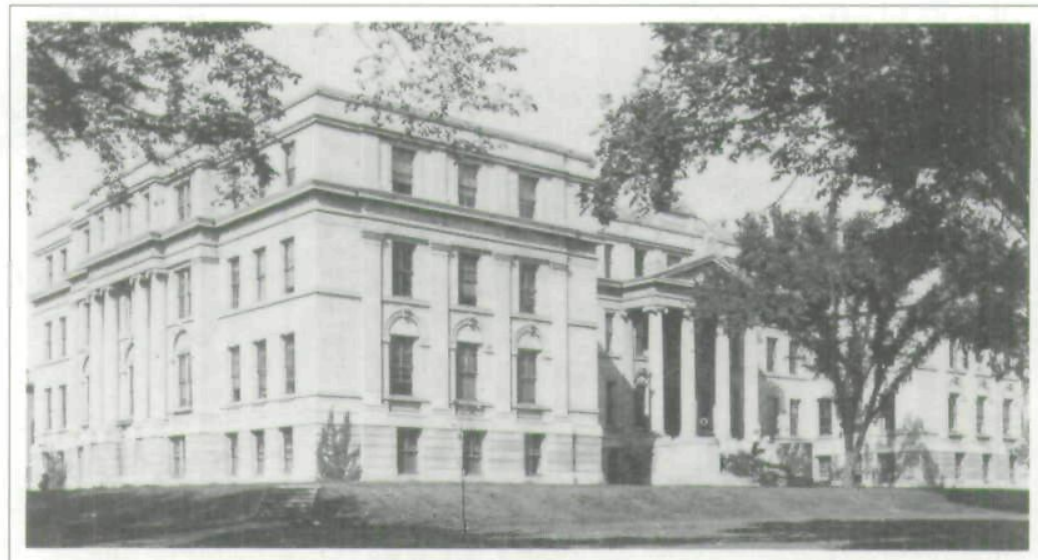

Fig. 9. Schaeffer Hall, 1898-1902. Courtesy of State Historical Society of Iowa, Iowa City.

alumni circulated petitions. "Save the Campus!" became the undergraduate battle cry, and a local newspaper editor echoed their theme. "The campus is a beautiful plot of ground," he wrote, "and to mutilate it seems almost a desecration to our people and the alumni, particularly as there is no need in so doing. ${ }^{\prime 21}$ This editor and others insisted that the board should adhere to the former Victorian landscape plan. That would have required that any new buildings be erected in a line with or behind Old Capitol, on the sites of several older buildings (including South Hall, North Hall, and the Medical Building, all of which were in various states of disrepair).

In a sense, the newspaper editor had assessed the situation accurately. The implementation of the Beaux-Arts scheme not only reduced the amount of available green space, but it drastically changed the character of the space as well. The Old Capitol area had been a wooded, park-like space, valued for its pastoral qualities; in the newer, more formal arrangement, however, the architecture dominates and even shapes the green space. Today (as then) this area is perceived not as a park but more as a showcase to set off the architectural ensemble. This domination of the landscape by architecture, often by creating strong axial lines in the green spaces echoing those of the buildings, is typical of Beaux-Arts planning.

21. Iowa City Republican, 27 April 1898. 
Although the evidence is not conclusive, it appears that Henry Van Brunt settled the long-standing controversy over the location of the new building, Schaeffer Hall. The official report on the University of Iowa campus planning made by the nationally known architectural landscape firm, Olmsted Brothers of Brookline, Massachusetts, stated that "the primary design for the disposition of buildings on the Old Capitol campus suggested by Messrs Van Brunt and Howe is an excellent one and should be realized by the erection of the two buildings contemplated southwest and northwest of the Old Capitol building respectively." Thus, by fixing Schaeffer Hall in its present location, somewhat forward of Old Capitol, with symmetry as a guide, the campus planners paved the way for the subsequent five-part arrangement. ${ }^{22}$

The Olmsted Brothers' report not only ties Van Brunt to the origin of the plan; it also links the whole scheme once more with the Stanford University campus plan and the Columbian Exposition. The university hired the Olmsted Brothers firm in 1905 as campus planning consultants. That firm was then being run by John Charles Olmsted and Frederick Olmsted, Jr. It is not surprising that Van Brunt's program for Iowa would find favor with the Olmsted brothers, since it reflected principles of campus planning introduced twenty years earlier at

22. Report of the Olmsted Brothers Outlining Plans for Future Arrangement of Buildings and Grounds of State University of Iowa (Iowa City, 1905), 4-5. The Minutes of the Board of Regents, 29 March 1898, indicate that after a meeting with Van Brunt, the board voted to rescind an earlier decision on the building's location and to place it where the building stands today: "Collegiate building to be located east of Old South Hall and medical buildings, facing East and as near said building and the south line of the campus as practicable." See also Henry Van Brunt to W. J. Haddock, 9 April 1898, Schaeffer Hall file, University of Iowa Archives. In this letter acknowledging receipt of his fee, Van Brunt indicates that it was his idea to change the location of the building: "Accept my thanks for the check. ... say to the Board I am much gratified by their expressions of appreciation of my service. ... the testimony conveyed was agreeable, and it would be even more agreeable if the Regents act according to my advice in regard to location of the new building." Contemporary local newspaper accounts also lend credence to the notion that Van Brunt was responsible for the Pentacrest conception. See, for example, Iowa City Weekly Republican, 5 April 1898: "The Board was very much influenced by the endorsement of very high authority-Henry Van Brunt, the famous architect of Boston and Kansas City. . . . his word carried great weight with the board." 
Stanford University by their father, Frederick Law Olmsted, who had also directed the site planning for the Columbian Exposition. ${ }^{23}$ With the Olmsteds' seal of approval, then, the implementation of the Pentacrest plan proceeded.

In 1924, with the completion of the fifth and final building in the group, the central campus at Iowa was named the Pentacrest, even though several substantial Victorian-era buildings were still intact and in place beside the four new classical structures. ${ }^{24}$ By that time, apparently, the Beaux-Arts plan was persuasive enough to exist unsullied, at least in people's imaginations. Yet the last remnant of the older, picturesque tradition was not eliminated until 1975, when a red brick building known locally as Old Dental was destroyed. With the removal of this obstruction, the central campus presented an entirely neoclassical aspect to the town, and Old Capitol could at last be seen from the north as well as east, west, and south, framed by the four monumental buildings that completed the Pentacrest (fig. 1).

WITH THE IMPLEMENTATION of the new Pentacrest design, the University of Iowa entered the mainstream of modern campus planning of the period. The university was eager to expand its facilities and present itself as an institution of academic excellence, on a par with better known or more established colleges and other institutions. The Beaux-Arts approach to design was ideally suited to handling the complex planning problems facing expanding universities such as the University of Iowa, for, as Paul Turner has noted, "its principles of monumental organization facilitated orderly planning on a grand scale and were capable of including many disparate buildings or parts within a unified overall pattern." ${ }^{\prime 25}$

With the impetus and direction provided by such prestigious figures in American architecture and landscape planning

23. Paul Turner, Founders and Architects, 63 , has pointed out that the Olmsted sons preferred the Stanford plan to other campus arrangements devised by Frederick, Sr., which tended to be more informal, like the Iowa State campus plan.

24. Daily Iowan, 19 December 1924. The most prominent of the remaining structures was North Hall, built in 1860 and torn down in 1948 .

25. Turner, Campus, 167. 
as Henry Van Brunt and the Olmsted Brothers, the university followed the national trend in choosing a fashionable design in the Beaux-Arts Classicism mode as the one best suited to present its new image and to realize its needs. A plan of imposing formality and monumentality, the design was public rather than collegiate, urban rather than rural. Henry Van Brunt understood clearly what the Iowans were seeking and summed up their aspirations when he described the design to a newspaper reporter as "elegant and dignified, classic and beautiful."26 What university officials really desired was not "Iowa Renaissance" after all, but American Renaissance, with its reassuring symbolic linkage of both the university and the nation with a glorious classical past.

Time has unexpectedly and ironically altered the significance of the Pentacrest, but most viewers would agree that it has aged well. The area of Iowa City adjacent to the Pentacrest, however, has experienced the trauma of an urban renewal program. Many of the nearby small-scale commercial buildings have been replaced by large, starkly modern parking ramps and a block-long shopping mall. Thus, the irate nineteenth-century newspaper editor would be happy to know that his beloved campus, though altered in aesthetic character, is probably valued now more than ever. It is still the "heart" of the campus, but it also provides a refreshing urban green space in downtown Iowa City, and is a historic landmark as well.

26. Iowa State Press, 6 April 1898. 
Copyright of Annals of Iowa is the property of State of Iowa, by \& through the State Historical Society of Iowa and its content may not be copied or emailed to multiple sites or posted to a listserv without the copyright holder's express written permission. However, users may print, download, or email articles for individual use. 